\title{
CULPA IN CONTRAHENDO EN MUTUO HIPOTECARIO*
}

\author{
CULPA IN CONTRAHENDO IN MORTGAGE LOAN
}

\author{
Marcelo Barrientos Zamorano**
}

RESUMEN: Analizaremos un caso fallado por culpa in contrahendo, en un mutuo hipotecario no financiado por parte de un banco comercial a un particular que se lo solicitó. Para ello haremos un estudio crítico de varias normas jurídicas. Todo con el fin de determinar si concurrió en el caso particular formación del consentimiento o no y cómo esta apreciación puede cambiar con las nuevas normas de la ley del consumidor chilena, introducidas por la ley 20.555 en la ley 19.946 .

Palabras clave: Culpa in contrahendo, responsabilidad precontractual, mutuo hipotecario, consumidores.

ABSTRACT: We will analyze a final judgment in a precontractual liability case about a mortgage loan not granted by a bank. This commentary will make a critical analysis of various legal rules. All in order to determine if in this case did exist or not agreement that usually proved by showing an offer by one party and acceptance of it by the other, and how this interpretation may change with the new rules of consumer's law introduced recently.

Key words: Culpa in contrahendo, precontractual liability, mortgage loan, consumers.

\section{INTRODUCCIÓN}

¿Cuánto tiempo se han demorado en aprobarle a usted un crédito hipotecario en un banco? ¿Días, meses o nunca recibió respuesta? ¿Envió al banco respectivo todos los antecedentes que le pidieron y este le contestó oportunamente? ¿Firmó un contrato de promesa de compraventa de una casa, a la espera de un crédito hipotecario? ¿Pidió un crédito de consumo o "enlace" a la espera del estudio de títulos de la propiedad? Pues bien, el caso que analizaremos tiene todas estas preguntas, varios meses de espera, perjuicios, demandas, malos ratos y algunas respuestas.

El fallo es de nuestra Corte Suprema, de doce de abril de dos mil doce para ser más exactos, fue caratulado "Urrea Fuentes, Cristian con Corpbanca", y servirá para que podamos ver el antes y el después que generó, en la ley de protección de los consumidores y

\footnotetext{
* Este trabajo forma parte de la investigación realizada en el marco del Proyecto de Investigación: INICIO/ $\mathrm{N}^{\circ}$ 1/ 2011, titulado "Responsabilidad civil en las tratativas preliminares de un contrato", el que es financiado por la Vicerrectoría de Investigación de la Pontificia Universidad Católica de Chile. Quisiera agradecer las interesantes reflexiones y correcciones a este trabajo hechas por los profesores Dr. Patricio Carvajal y Dr. Juan Luis Goldenberg. Los errores que persistan, son de mi total responsabilidad.

** Profesor de Derecho Civil de la Pontificia Universidad Católica de Chile.

Doctor en Derecho con mención “Doctor Europeus”, Universidad de Salamanca, España. Magíster en Derecho de la Empresa, Pontificia Universidad Católica de Chile. Abogado.

1 Sentencia pronunciada por la Primera Sala de la Corte Suprema por los Ministros Sres. Sergio Muñoz G., Juan Araya, E., Guillermo Silva G., Carlos Cerda F. y el Abogado Integrante Sr. Nelson Pozo S. Rol No 218-2011.
} 
usuarios, la dictación de la ley 20.555, de cinco de diciembre de dos mil once, entre otros aspectos.

Los hechos de la causa son los que siguen. Un cliente de banco, para adquirir una casa, presentó a la institución financiera los antecedentes que le fueron requeridos para la obtención de un "crédito hipotecario", entre otros, el precio de la propiedad y aquellos relacionados con sus ingresos. Al poco tiempo, le fue informado por medio de un correo electrónico que su "crédito hipotecario" había sido "aprobado en su integridad", por medio de un crédito con letras de recompra al cien por ciento, por un monto de mil veintitrés U.F., además de un crédito complementario de siete millones de pesos, a fin de hacer las adecuaciones necesarias en el inmueble. Esta situación, también fue comunicada por el banco a la empresa constructora del inmueble, a quien además se le solicitó la remisión de los antecedentes legales y técnicos de la propiedad para el estudio de títulos respectivos. En tal contexto, se le advirtió a la institución bancaria que, gracias a la aprobación del crédito, procederían las partes del contrato a firmar una promesa de compraventa, solicitándosele que les confirmara el monto del crédito y plazo conferido al cliente para el otorgamiento del préstamo. La institución bancaria accedió a esta solicitud, informando que se trataba de un crédito a 20 años, sin perjuicio de que se otorgaría en carácter de complementario uno por siete millones de pesos. Este último crédito fue cursado de inmediato.

El caso resulta interesante por muchas razones, entre otras, porque en la convicción de que el crédito hipotecario se encontraba aprobado, y que solo restaba el estudio de los títulos ${ }^{2}$, el cliente del banco procedió a celebrar el contrato de promesa de compraventa con la constructora, promitente vendedora, y esta le hizo entrega de la propiedad. No solo eso, el cliente contrató con el mismo banco un crédito complementario, dineros con los que procedió a realizar diversas obras al interior del citado bien raíz. Sin embargo, diez meses después, el banco comunicó al cliente que no aprobaría el crédito, en atención a su recarga financiera ${ }^{3}$.

Los hechos de esta causa pueden verse afectados por la nueva normativa surgida para proveedores y consumidores a partir de la ley 20.555, publicada el 5 de diciembre de 2011, y que modificó la Ley 19.496 sobre Protección de los Derechos de los Consumidores, agregando nuevos derechos para los consumidores y dando también nuevas atribuciones al Servicio Nacional del Consumidor ${ }^{4}$. Creemos que es así porque se ha modificado la forma

\footnotetext{
2 Estos documentos si bien no serían expresión de voluntad, tendrían valor probatorio de existencia de negociación. Aunque en este caso que estamos analizando, a nuestro juicio, sí se forma el consentimiento. RAVAzzoNI (1966) pp. 57. Como sabemos, no hay propiamente una relación jurídica en los tratos, pero ello no significa que no sean importantes per se, ya que es evidente su proyección a la formación del vínculo contractual definitivo y, sobre todo, en su interpretación. Ferrara (1940) pp. 173. Carrasco Perera (2010) pp. 127 y ss.

3 La doctrina tradicional topa con un problema aquí, pues el comprador dañado -que habiendo confiado en la validez del contrato, veía defraudados sus intereses- carecería de acción contractual (el contrato era nulo) y de acción extracontractual (el caso no encaja en ningún supuesto de la Lex Aquilia). Sobre este problema en perspectiva histórica, Medina Alcoz (2005) No 5-6.

4 La historia de la norma se encuentra disponible en: http://www.leychile.cl/Consulta/portada_hl?tipo_ norma=XX1\&nro_ley=20555\&anio=2012 [fecha de consulta: 6 de junio 2012]. Los matices del nuevo artículo 17 A) a L) y otras disposiciones modificadas a lo largo de la ley de la ley 19.496, transitan por diferentes derroteros jurídicos que parecieran tener su punto de partida en el nuevo artículo $3^{\circ}$ inciso segundo de la ley 19.946,
} 
de los contratos de consumo en general y ello supone el nacimiento de una regulación legal expresa, con definición incluida, de los créditos hipotecarios dentro de los productos financieros.

En la nueva ley están mezclados conceptos muy diversos, entre otros financieros, y que no inciden todos ellos de la misma manera en la formación del contrato de consumo en general, su ejecución y terminación. Así, por ejemplo, en los nuevos artículos 17 A) a L) y otras disposiciones modificadas a lo largo de la ley 19.496, hay normas sobre información previa y posterior a la celebración del contrato entre las partes y terceros; propias de contratos de adhesión; de promoción de servicios; de caducidad de ofertas; de carga anual equivalente; de condiciones objetivas para el crédito del producto financiero; de mandatos en blanco y revocación; de error en la contratación y sus efectos e incluso, de problemas relacionados con la cláusula general hipotecaria, entre otros más 5 .

Creemos que para analizar un caso como el que motiva este trabajo, y por los linderos de este tipo de investigación jurídica, nos abocaremos al estudio de cuatro aspectos:

1. Regulación en las normas de la Superintendencia de Bancos e Instituciones Financieras para el otorgamiento de mutuos hipotecarios endosables.

2. Si en el caso particular se celebró el consentimiento.

3. Si concurre en la especie responsabilidad precontractual.

4. Impacto de la ley 20.555 en la litis trabada en este caso.

\section{REGULACIÓN EN LAS NORMAS DE LA SUPERINTENDENCIA DE BANCOS E INSTITUCIONES FINANCIERAS PARA EL OTORGAMIENTO DE MUTUOS HIPOTECARIOS ENDOSABLES Y DEL COMPENDIO DE NORMAS FINANCIERAS DEL BANCO CENTRAL}

Las normas referidas señalan algunas limitaciones a los bancos en el otorgamiento de los créditos hipotecarios. Es de este tipo aquella que señala que los préstamos que otorguen los bancos bajo esta modalidad, no podrán exceder del ochenta por ciento del valor de tasación del inmueble ofrecido en garantía, ni exceder del mencionado importe o del ochenta

el que, a grandes rasgos, plantea la necesidad de que el consumidor reciba la información del costo total del producto o servicio, lo que comprende conocer la carga anual equivalente a que se refiere el nuevo artículo 17 G, y ser informado por escrito de las razones del rechazo a la contratación del servicio financiero, las que deberán fundarse en condiciones objetivas. Agrega este artículo 3 inciso $2^{\circ}$, que el consumidor tiene derecho a conocer las condiciones objetivas que el proveedor establece previa y públicamente para acceder al crédito y para otras operaciones financieras. Se sostiene, en fin, por la nueva legislación que el consumidor tiene derecho a la oportuna liberación de las garantías constituidas para asegurar el cumplimiento de sus obligaciones, una vez extinguidas estas; a elegir al tasador de los bienes ofrecidos en garantía, entre las alternativas que le presente la institución financiera y conocer la liquidación total del crédito, a su solo requerimiento.

5 Para órdenes jurídicos a considerar en este punto, sin perjuicio que la ley chilena ofrece peculiaridades propias, es preciso tener en cuenta la ley española, norteamericana e inglesa ya que, de acuerdo a la génesis de la ley chilena, estas leyes fueron consideradas ampliamente en su discusión y reformas. http://www.leychile.cl/ Consulta/portada_hl?tipo_norma=XX1\&nro_ley=20555\&anio=2012 [fecha de consulta: 6 de junio 2012]. En consecuencia, entre otros, Larrosa Amante (2011) pp. 5 y ss.; Rebollo Puig (2011) pp. 2088, entre otros. 
por ciento del precio de venta del respectivo inmueble, si este último precio fuere inferior al valor de tasación ${ }^{6}$.

Para el caso que nos ocupa es importante tener en cuenta que en la tasación del inmueble que debe practicarse, solo se comprenderá el valor de las mejoras permanentes adheridas a este, de manera que no necesariamente el préstamo solicitado por el demandante de siete millones y fracción debería ser utilizado en la tasación del bien.

En el caso de la ley general de bancos, de conformidad al artículo 40 y el numeral $3^{\circ}$ del artículo 69 de la misma ley, los bancos podrán hacer préstamos con o sin garantía y, el número $7^{\circ}$ de la misma norma, agrega que los bancos podrán otorgar créditos que se encuentren amparados por garantía hipotecaria ${ }^{7}$.

De esto podemos concluir que, al menos en las normas de la superintendencia de bancos e instituciones financieras para el otorgamiento de mutuos hipotecarios endosables, no es forzoso que los créditos otorgados por los bancos solo puedan serlo con garantía hipotecaria. Pueden, eventualmente, los bancos otorgar créditos con otros tipos de cauciones, reales o personales.

En el caso que comentamos, válido es cuestionarse el porqué el banco no podía asegurar el cumplimiento del mutuo con una caución distinta de la hipoteca y con ello, no terminar negando el otorgamiento del crédito hipotecario una vez que ya lo había aprobado por correo electrónico al cliente. Tal y como consigna el fallo, le fue informado al demandante en la causa, por medio de un correo electrónico, que su crédito hipotecario había sido aprobado en su integridad, por medio de un crédito con letras de recompra al cien por ciento, por un monto de mil veintitrés U.F., además de un crédito complementario de siete millones de pesos, a fin de hacer las adecuaciones necesarias en el inmueble. Esta situación, también fue comunicada por el banco a la empresa constructora, a quien además le solicitó la remisión de los antecedentes legales y técnicos de la propiedad para el estudio de títulos respectivo. Precisamente en esto se centra la imposibilidad de remplazar esta caución por otra, por lo que el banco demandado no tenía forma de recurrir a otras cauciones.

Más explícita es, en este sentido, la reglamentación del compendio de normas financieras del Banco Central y que debe complementar las normas de la Superintendencia de Bancos e Instituciones Financieras para estas materias ${ }^{8}$. Señala, en la parte pertinente,

6 Circular $\mathrm{N}^{\circ} 3.427$ / 27.02.08 SBIF, disponible en http://www.sbif.cl/sbifweb3/internet/archivos/norma_180_1.pdf (fecha de consulta 3 de septiembre de 2012).

7 Ley General de Bancos, cuyo texto fue fijado por el artículo único del decreto con fuerza de ley No 3, de 1997, del Ministerio de Hacienda. Modificada por la ley 20.448, artículo 9 número 2. "Asimismo, y con sujeción a las normas generales que dicte la Superintendencia, los bancos podrán emitir bonos sin garantía especial, con el objeto de destinar los fondos recibidos exclusivamente al otorgamiento de mutuos que se encuentren amparados por garantía hipotecaria para el financiamiento de la adquisición, construcción, reparación o ampliación de viviendas. Esta circunstancia deberá consignarse en la escritura de emisión correspondiente, junto con el plazo máximo de otorgamiento de dichos créditos con cargo a los fondos obtenidos en la colocación y con las condiciones de rescate anticipado en caso de incumplimiento de lo señalado anteriormente. Asimismo, se hará referencia de tales circunstancias en la correspondiente emisión de bonos".

8 El Banco Central en su Compendio de Normas Financieras, tiene reglas sobre Sistemas de Financiamiento; Operación, Intermediación y Control del Sistema Financiero y Mercado de Capitales; Operaciones del Banco Central de Chile con Instrumentos Financieros; y Operaciones de Empresas Bancarias y Sociedades Financieras en moneda extranjera. Dentro de las primeras, las de Sistemas de Financiamiento, en la letra A se especifican 
que "En conformidad a lo dispuesto en el Título XIII de la Ley General de Bancos, las empresas bancarias deberán observar las siguientes normas en sus operaciones hipotecarias con letras de crédito.

I. Normas sobre préstamos hipotecarios mediante emisión de letras de crédito.

1. Las empresas bancarias, en adelante indistintamente "el emisor", podrán otorgar préstamos caucionados con hipoteca mediante la emisión de letras de crédito por igual monto que aquéllos".

Ratifica esta disposición, en carácter de imperativo, la misma norma referida cuando señala que, en lo relativo al "Préstamo hipotecario y valor de la garantía. 9. Los préstamos en letras de crédito deberán garantizarse con primera hipoteca sobre inmuebles. Esta garantía no podrá caucionar otras obligaciones, sin perjuicio de constituirse otras hipotecas de grado posterior" 9 .

En conclusión, las normas del Banco Central analizadas son las que no permitirían al banco demandado en esta causa, el otorgamiento de un crédito hipotecario, con letras de crédito, sin caución hipotecaria. Así, los mutuos en letras de crédito deberán garantizarse con hipoteca sobre inmuebles, no pudiendo otorgarse mutuo de estas características con otras cauciones como prendas o fianzas.

\section{SI EN EL CASO PARTICULAR SE CELEBRÓ EL CONSENTIMIENTO}

A nuestro juicio sí hubo consentimiento en el otorgamiento del "crédito hipotecario". Lo hubo porque el consentimiento se forma, al menos, en el contrato de mutuo consensualmente, si bien para la hipoteca se requiere solemnidad. Es por esto que el contrato de mutuo es, al fin y al cabo, por escritura pública en estos casos. Acompaña en la solemnidad al contrato de garantía que le accede, la hipoteca, y el de compraventa de bienes raíces, por la compra de la casa. Las reglas de los artículos 2409 inciso primero y 1801 inciso segundo del Código Civil, prescriben la solemnidad de tales actos. Este mutuo es un contrato de consumo perfecto cuya eficacia queda condicionada suspensivamente, $y$, en este sentido, vinculada a la conformidad del estudio de los títulos de la propiedad y al hecho de estar ellos conforme a derecho.

Tan formado quedó el consentimiento en el mutuo que, según consta en autos, se comunica al actor por mail, que el Banco ha aprobado un crédito hipotecario financiado en un cien por ciento mediante crédito con letras con recompra al cien por ciento, más un crédito complementario de siete millones, a fin de hacer las adecuaciones necesarias en la propiedad en cuestión. No solo eso, se le comunica la misma noticia a la constructora de la casa para que envíe los antecedentes legales y técnicos del inmueble. Es más, esta es la razón por la que cerca de veinte días después se celebró un contrato de promesa de compraventa y se hizo entrega del inmueble que se pretendía comprar al cliente del Banco, procediéndo-

las de "A.- Financiamiento para la vivienda" y en el Capítulo II.A.1 "Normas sobre operaciones hipotecarias con letras de crédito". Disponible en http://www.bcentral.cl/normativa/normas-financieras/index.htm, fecha de consulta: 24 de septiembre de 2012.

9 Acuerdo $N^{\circ}$ 1495-03-090820 - Circular No 3013-652. 
se a abonar el crédito complementario anexo al referido mutuo hipotecario. Los actos contemporáneos y ulteriores al contrato, que deben tomarse en consideración para comprender la verdadera intención de los contratantes al contratar, hablan por sí mismos en cuanto a la intención de las partes.

La confianza entre las partes, en este caso, surge de hechos concluyentes de ellas en las negociaciones, pues es provocada por actos o actitudes que se consideran vinculantes para la persona que los lleva a cabo, lo que en este caso, dio origen incluso a nuevos contratos relacionados. Aquí hay una conducta concluyente del banco, que no es la base de un acuerdo sobre un futuro crédito hipotecario, este ya existe y se le comunicó como aprobado y por escrito al correo electrónico del cliente. La oferta y la aceptación ya se encontraron en el consentimiento.

Es efectivo que en los sistemas continentales de derecho hay una, a nuestro juicio, aparente rigidez que se decanta en la imperiosa necesidad de concurrencia de todos los elementos esenciales de la oferta como regla general, no obstante, derechos romanos germánicos como el alemán o suizo, presumen que el contrato puede existir aun en la falta de acuerdo sobre alguno de los elementos esenciales ( $\$ 155$ BGB; art. 2.2 Código de las obligaciones suizo).

Estimamos que en la especie, notoriamente a nuestro juicio, concurre un consentimiento formado, que da origen a nuevos contratos incluso, pero entonces por qué no cerrar todo y no discutir más sobre el asunto. No es tan simple, ni en Chile ni en el extranjero. Hay cierta unanimidad en el derecho comparado y nacional cuándo se forma el consentimiento ${ }^{10}$, sin embargo la paz en este punto se diluye cuando enfrentamos otro problema: ¿cuándo se llega a la convicción de que hay un consentimiento contractual o acuerdo de voluntades?

El Common Law, sigue sus propias reglas, las que se ordenan desde la concurrencia de una interpretación objetiva de los hechos. En el sistema anglosajón lo importante en la declaración de una de las partes a la otra (como lo fue en el caso que comentamos el email que confirmaba el otorgamiento del crédito), es que objetivamente ello sea interpretado por un juez como consentimiento formado ${ }^{11}$. Esto no hace más que proteger el tráfico jurídico. La intención del oferente de quedar vinculado con su declaración se desprende de lo que ha dicho o hecho. El tribunal, de conformidad con un test objetivo, se coloca en la posición de quien recibió la comunicación ${ }^{12}$. Se protege a la parte que cree razonablemente lo que la otra ha dicho o hecho, auténticas expectativas razonables de un hombre honesto ${ }^{13}$.

10 Art. 154.1 BGB, arts. 861-864 AGBGB austríaco; arts. 1.254, 1.258, 1.261 y 1.262 del Código Civil (en adelante CC) español, art.108 del CC francés, belga y de Luxemburgo; arts. 185-192 CC de Grecia; arts. 1.321 y 1.325 del CC italiano, el art. 232 del CC de Portugal, el art. 1 del Código de obligaciones suizo, art. 432 CC de la Federación Rusa, por citar algunos.

11 Así se lee en Butler Machine Tool Co Ltd v. Ex-Cell-O Corporation (England) Ltd [1979] 1 WLR 401 (CA) 404.

12 En el Derecho británico surgiría la obligación de actuar de buena fe, solo si existe contrato o si una carta de intenciones crea un acuerdo completo. Hoog (2011) pp. 235 y ss.

13 Por todos, los lúcidos comentarios en el caso G. Percy Trentham Ltd v Archital Luxfer Lid [1993] 1 Lloyd's Rep 25 (CA) 27. 
No es de extrañar que la Convención de Viena (art. 23 y 18.2), los Principios Europeos de derecho de los contratos (art. 2:205) o el Marco Común de Referencia (artículo 4:205) estén de acuerdo en diferenciar el modo en que se ha manifestado la aceptación, vinculando el momento de perfección del contrato con el de efectividad de la aceptación.

Como puede apreciarse, y llevado al caso que analizamos, el consentimiento se formó y esto es lo que cabría pensar en cualquiera de los cuerpos legales citados, de derecho vigente y los que pretenden unificación del derecho continental y anglosajón.

Entonces, qué rol cumple el estudio de títulos en el caso que estamos analizando. Este no es más que una condición suspensiva a nuestro juicio.

Estamos frente a un contrato de préstamo vinculado a un contrato de consumo y compraventa, no debemos olvidarlo. El contrato de consumo se recibe expresamente para hacer pago de refacciones producto de la futura venta, así, el contrato de adquisición, y el de financiación, se presentan causalmente vinculados.

Esta vinculación quedó especialmente de manifiesto en que se perdió eficacia del primero, por la negativa del banco a financiar posteriormente el crédito ante la falta de conformidad en el estudio de los títulos, lo que provocó también la pérdida de eficacia del segundo crédito. En relación a esto, no deja de llamar la atención de que la Corte fijara en siete millones de pesos la indemnización por daño moral en este caso, este es el mismo monto solicitado al banco para refaccionar la casa que se pretendía comprar. Curioso, la Corte da una nueva interpretación a la indemnización por daño moral, lo que no hace sino confirmar que hoy por hoy, sigue el quantum indemnizatorio teniendo las motivaciones que mejor parezcan a la sentenciadora, en este caso, el crédito de financiación. La Corte en la sentencia que nos ocupa literalmente "compensa" o "empata" prudencialmente los sufrimientos del solicitante del crédito, y la situación vivida, con el monto del crédito complementario de siete millones, a fin de hacer las adecuaciones necesarias en el inmueble que finalmente se tuvo que restituir a la constructora del mismo. Demasiado patrimonial, a nuestro juicio, es esta partida del daño extrapatrimonial para el máximo tribunal del país. No podemos menos que disentir con la forma de abordar esta cuantía indemnizatoria, estas debieran relacionarse con elementos muy diferentes a los tomados en cuenta por la Corte Suprema en su fallo, tales como el deterioro de calidad de vida, ansiedad, depresión en su caso, duración estos estados, gravedad, pérdidas de amenidades, todas demostradas en juicio por el que los alega, pero no el monto del crédito dado al demandante para reparar una propiedad ${ }^{14}$.

\footnotetext{
14 En los textos europeos encontramos aportaciones interesantes sobre esta estimación del daño no patrimonial, nos referiremos a tres de estos intentos de unificiación del Derecho europeo, los Principios Lando (arts. 9:501), los Principios Acquis (art. 8: 402) y el DCFR (III: 3701). En los PECL, el art. 9: 501: (2), relativo al Derecho a la indemnización de daños y perjuicios, en su apartado (1) advierte que: "(1) La parte perjudicada tiene derecho a una indemnización de daños y perjuicios respecto de las pérdidas sufridas a consecuencia del incumplimiento de la otra parte, siempre que este incumplimiento no quede cubierto por la excepción del artículo 8:108". Allí se lee, en el (2) que "Las pérdidas que cubre esta indemnización incluyen: (a) Pérdidas no pecuniarias y (b) Futuras pérdidas previsibles y probables". Para los Principios Acquis, en el art. 8:402 (4), sobre el alcance de la indemnización, señala que: "(1) La indemnización es el pago de la cantidad de dinero necesaria para restablecer la situación que hubiera correspondido al acreedor si la prestación hubiera sido cumplida debidamente. (2) La indemnización cubre el valor de la pérdida sufrida por el acreedor, incluida la ganancia que haya dejado de obtener. (3) Sin perjuicio de las normas sobre reembolsos de las costas judiciales, la indemnización incluye cualquier gasto adecuado
} 
¿Qué hacer en una situación como la descrita con la empresa vendedora de la casa que accedió a firmar una promesa de compraventa, autorizando la ocupación de la propiedad? ¿Qué pasa con los costos del banco, que remitió los antecedentes a su departamento legal para el estudio de los títulos, costos que en el caso particular se cargaron en la cuenta corriente del cliente? ¿Ahora que todo había sido rechazado, es útil al cliente el crédito complementario tomado para invertirlo en la vivienda que finalmente no se compró? $\mathrm{Ni}$ hablar en este caso de los problemas posteriores que este cliente del banco tuvo que padecer como consecuencia de las mejoras que introdujo en la propiedad. Aunque el problema más espinudo de todos fue que la sociedad constructora solicitó al cliente del banco la restitución de la casa y el pago de una renta de arrendamiento por el tiempo que la ocupó, en razón de no habérsele otorgado el "crédito hipotecario".

Es curioso cómo el común de la gente, en la vida diaria del tráfico jurídico, tiene una idea sobre precontratos como este que no se condicen con su enorme trascendencia jurídica. Estos contratos de promesa son auténticos contratos en sí mismos. Si lo pensamos detenidamente, el consentimiento de la promesa de compraventa, obligación de hacer, ya se encuentra formado. Si cabe alegar la nulidad de este contrato y su resolución, claramente las partes deberán restituirse recíprocamente las prestaciones realizadas. Pero no es esa la única solución, también aquí la ineficacia del contrato de crédito dará lugar a la ineficacia del de financiación para mejoras en la propiedad que se pretende comprar, cuyo efecto será que la constructora recupere el bien prestado en el estado en que se encuentre. En uno y en otro caso, las partes han actuado de buena fe, en la creencia de que el banco otorgaría el crédito hipotecario. No ocurrió finalmente así.

Creemos que en este caso, y gracias a la buena fe del solicitante del crédito hipotecario y la constructora, el banco debiera haber resarcido los daños causados a la constructora y haber abonado intereses (1559 CC). Todo esto a condición de que se hubiera constituido en mora al banco, por no haber respondido oportunamente el otorgamiento del crédito (1551 CC), sin embargo ello no se hizo. El juez pudo en un caso como este, con un poco más de diligencia por parte de los acreedores, haber dado lugar a la procedencia de una acción de cumplimiento específico o de una acción de daños, ya que si un sujeto incumple un acuerdo como la promesa firmada, que se asumió durante una negociación como consensuada, y que luego es desechada unilateralmente, evidentemente supone incumplimiento de obligaciones adquiridas. Las partidas propias de esta indemnización, entre otras, serán

para la ejecución de la obligación (4) La indemnización solo incluye los daños no patrimoniales, en la medida en que la finalidad de la prestación incluya la protección o la satisfacción de intereses no patrimoniales". Por último, para el DCFR es mejor distinguir entre pérdidas de carácter económico y no económico. Los primeros, serían la pérdida de ingresos o beneficios económicos o reducción en el valor de la propiedad. Así en el art. 111-3:701 (3), se cita expresamente el dolor, el sufrimiento y el deterioro de vida. El DCFR va más allá, establece el III - 3:701: Derecho e interés: "(1) El acreedor tiene derecho a indemnización del perjuicio causado por el deudor que incumple una obligación a menos que el incumplimiento sea justificado. (2) La pérdida de los daños incluye la pérdida de reembolso futuro, que es razonablemente probable que se produzca (3) Las pérdidas, incluidas las económicos y no económicas. La pérdida de carácter económico incluye la pérdida de ingresos o beneficios obtenidos y una reducción en el valor de la propiedad. La pérdida de carácter no económico comprende el dolor y el sufrimiento y el deterioro de la calidad de vida". Como puede apreciarse en el DFCR, cobran especial importancia, las pautas que se dan al juez para determinar cuantía y límites de indemnización de daños no patrimoniales en estos casos. 
las derivadas del uso y tenencia del bien por el consumidor y su depreciación comercial. Para este caso, estos intereses moratorios surgen de la aplicación también del artículo 173 del Código de Procedimiento civil, pero claro, quien debiera probar estos perjuicios es el acreedor. En la especie, se debieron pedir y devolver los frutos o indemnizar los perjuicios que significaron la dilación en la respuesta del banco a la aprobación de los títulos de la propiedad conforme a derecho y que sufrieron tanto el cliente del banco como la constructora, específicamente por el estado en que se devuelve el bien raíz ya usada casi un año.

Procesalmente, no se debe olvidar que, ya desde tiempos romanos, la importancia de los bonae fidei iudicium se vertebra en que las partes no estaban constreñidas por una concreta fórmula, lo que permitía al juez razonar y decidir el caso de conformidad con aquello que pareciera justo (equitativo) y razonable. Por este motivo, tal y como razona un autor, se relaciona la equidad con la buena $\mathrm{fe}^{15}$.

Para el caso en análisis, nos resulta meridianamente claro que algo más ha fallado, el deber de cooperación del banco para con el cliente. De la propia función normativa del principio general de buena fe se extraen un conjunto de deberes para las partes, con independencia de que estén previstos expresamente en el contrato, uno de ellos, el de cooperación. En este sentido, los derechos comparados consideran especialmente importante este deber en las operaciones complicadas y que se prolongan en el tiempo, la cooperación aparece como función integradora de varios contratos como ocurre en el caso que comentamos. Las actuales relaciones comerciales no obedecen a un simple intercambio de bienes sino más bien a formas de organización, producción y distribución de los recursos.

Estos deberes no son espontáneos, surgen de hechos objetivos y probados en esta causa como la recepción del correo electrónico, que tiene por lo menos un extenso contenido negocial de las partes, con valor de acuerdo definitivo sometido a condición suspensiva, como hemos señalado.

Detengámonos un momento en esta condición suspensiva del estudio de títulos. En este caso sometido a estudio, es una que roza la meramente potestativa. Si concurre dolo por parte del que se obliga con ella, en esta sentencia el banco, no valdrá, esto pues la condición se tendrá por cumplida, y el contrato estará perfecto, conforme al artículo 1448 del Código Civil. ¿¿Se tendría que haber dado por cumplida esta condición? La Corte Suprema no lo entendió así, por el contrario, comprendió que hubo determinación y cumplimiento de buena fe de la condición por parte del banco (casi un año después contestó que no financiaría el crédito hipotecario que ya había aprobado) y que el afectado por ella solo podría ser indemnizado por el interés de confianza de la otra parte, gracias a las tratativas preliminares. No nos parece adecuada esta interpretación, ya que abre la puerta a que no existiendo el suficiente grado de determinación, en vez de privilegiarse la interpretación que toma esto como un acuerdo de voluntades sujeto a condición suspensiva, privilegia en los hechos formas reticentes al cumplimiento del contrato mismo y salidas para el deudor que posibiliten el cumplimiento de su obligación, como ocurre con el banco en este caso,

15 WhitTaker S. et al. (2000) p. 17. 
que finalmente no quiso otorgar el crédito y que dejó pasar el tiempo excesivamente con perjuicio del acreedor y terceros ${ }^{16}$.

Lo que se debió analizar en este caso por la Corte era la voluntad de los contratantes, que es posible de colegir de los hechos probados en juicio y el fin de protección del contrato. En definitiva, los riesgos asumidos por el deudor, que son los que de acuerdo al artículo 1558 del Código Civil, nos darán el alcance de los daños indemnizables al tiempo del contrato, esos que se previeron o pudieron preverse. Esta previsibilidad del daño indemnizable sirve como criterio objetivo de interpretación para lo que hemos señalado, pero no es lo único. En ellos se encierran, como han tenido oportunidad de analizar varios autores de derecho comparado: el deber de mitigar el daño y el ejercicio compatible, por el acreedor, de otros remedios del incumplimiento del contrato en cuanto le puedan permitir, retener o recuperar recursos económicos que, de haberse cumplido el contrato, hubieran debido ser transferidos al acreedor, en el caso que analizamos, al cliente del banco. Tal ventaja debe compensarse con el daño para evitar un enriquecimiento injusto del acreedor ${ }^{17}$.

Solo para tener una idea en este punto y apreciar hacia dónde se mueve el derecho civil actual, veamos la solución de la Convención de Viena, ley en Chile vigente para la compraventa internacional de mercaderías ${ }^{18}$. Aquí es habitual la medida mitigadora de realizar una razonable transacción de reemplazo cuando sea procedente la resolución del contrato. En este caso, la cuantía de la indemnización queda fijada por la diferencia entre el precio del contrato y el de la operación de reemplazo, sin perjuicio de otros daños indemnizables con arreglo al artículo 74 de la Convención de Viena ${ }^{19}$.

\section{SI CONCURRE EN LA ESPECIE RESPONSABILIDAD PRECONTRACTUAL}

Es discutible. No se pueden confundir los tratos preliminares, y las negociaciones tendentes a la perfección del contrato, con la celebración efectiva del contrato mismo. Por lo pronto, aquí tenemos a un contratante, el banco, que entrega informaciones inexactas (envía un correo electrónico que dice aprobar un crédito hipotecario) y se sirve de ello (aprueba otro crédito para mejoras en la propiedad del deudor). No toma medidas para contrarrestar sus inexactitudes, más bien genera confusión y perjuicios en el deudor al dilatar la notificación del rechazo, en definitiva, del crédito hipotecario por disconformidad en la apreciación de las cauciones que acceden a los negocios principales. Podría serle imputable un daño causado al otro contratante en la fase precontractual, que es el criterio que sigue la Corte Suprema en su fallo, pero no es el único camino que se pudo haber elegido.

\footnotetext{
16 Sobre el escaso tratamiento en doctrina de los silencios reticentes, De la Maza Gazmuri (2010) pp. 455 y ss.

17 Morales Moreno (2010) p. 169.

18 A grandes rasgos, la Convención de Viena sistematiza un concepto amplio de compraventa, buscando uniformar las respuestas jurídicas al tráfico internacional de mercaderías, simplificando el incumplimiento contractual y sus efectos. En Chile el Decreto Ley No 3.633 de mayo de 1981 y el Decreto Supremo No 381 de 1981, del Ministerio de Relaciones Exteriores, publicados en el Diario Oficial de 22 de junio de 1981, los recogen como ley de la República, en el mismo rango legal, en consecuencia, que el Código Civil.

19 Para un amplio análisis en derecho comparado y chileno, Vidal Olivares (2011) pp. 243 y ss.
} 
Si hubiera que señalar un denominador común para todas las doctrinas que se han pronunciado sobre la culpa in contrahendo este, sin duda, pivota sobre la necesidad de indemnizar el daño ocasionado por defraudar inicuamente la confianza en la honorabilidad ajena ${ }^{20}$. Dudamos que esta sea la única forma de entender el caso que comentamos, la de la responsabilidad in contrahendo, ya que el problema de esta responsabilidad, y a nivel de derecho europeo es igual, es que nunca ha existido un claro acuerdo sobre dos cuestiones centrales: sobre el fundamento de dicha responsabilidad, especialmente en aquellos códigos civiles que contienen reglas especiales, y sobre el alcance y delimitación de las hipótesis que, dentro de tal regla, no especialmente consagradas por las leyes, pueden entenderse incluidas. Es especialmente crítico este último punto ${ }^{21}$.

Resulta claro que aquí se creó confianza entre las partes de que el crédito hipotecario se otorgaría, apreciable objetivamente de acuerdo a la sentenciadora. Este se relaciona con la persuasión que el actuar de una parte hace razonablemente generar en la otra, es decir, la seguridad en el cumplimiento de un negocio jurídico determinado. La existencia de esta clase de responsabilidad extracontractual debe pasar necesariamente por la creación de una situación de confianza, luego defraudada injustificadamente. La negociación que se realizó fue un proceso de construcción de un punto de encuentro entre los diversos intereses de las partes. Auténtica estructura base de cooperación contractual futura. El ordenamiento jurídico tutela la confianza precontractual legítimamente despertada, lo que no quiere decir que se deba tutelar toda esperanza o expectativa nacida entre los interesados, solo las confianzas legítimas deben serlo, pues lo reprochable es la generación de una expectativa falsa acerca de la conclusión del contrato. Sí, esto también ocurrió en este caso, y es lo que señaló en su fallo la Corte Suprema.

No es la única vía que se podría argumentar, es cierto también. La responsabilidad por información incorrecta puede configurar error esencial, ex artículo 1453 del Código Civil, y acarrear nulidad del contrato, lo que se defiende por algún autor ${ }^{22}$. Sin embargo, también podría pensarse en un error accidental, ex artículo 1454 inciso segundo del Código Civil, vicio de nulidad relativa, ya que consta en la promesa entre el cliente y la constructora el otorgamiento del crédito hipotecario por parte del banco demandado. Entonces, puede argumentarse que es el principal motivo de una de las partes para contratar y, por lo demás, es claro que en el caso este motivo ha sido conocido de la otra parte.

El problema, sea que se adopte para el caso el error esencial o accidental, es que la información imprecisa del banco se incorpora al contrato y, como hemos afirmado más arriba, a otros contratos con terceros, como en este caso ocurrió con la promesa de compraventa celebrado con la constructora. Las partes y los terceros se vincularon gracias a esas informaciones inexactas. Si se recibe un mail que aprueba un crédito hipotecario y con ello se genera un contrato de promesa con una constructora y un nuevo crédito, no estamos simplemente frente a un problema in contrahendo, es ya un problema contractual. El banco, conforme a sus declaraciones y acciones, garantiza al cliente su interés en que el contra-

20 Manzanares Secades (1985) p. 699.

21 Díez-Picazo et al. (2002) p. 197.

22 Sobre el particular, véase De la Maza Gazmuri (2010) pp. 455 y ss. 
to se celebre. En clave moderna de obligaciones, ese interés ha de satisfacerse "a través de la pretensión de cumplimiento, cuando es posible, o de la pretensión de indemnización de daños (interés positivo)"23.

Tal y como hemos explicado anteriormente en otros trabajos, la indemnización del "interés positivo" no requiere el desistimiento del negocio válido, antes bien, presupone su ejecución, aunque en vez de cumplimiento efectivo -el cual resulta imposible o carece de interés para el declarante- exige otro objeto, subsidiario a la prestación principal. La demanda tiene su base en el contrato o negocio jurídico válido y perfecto que está plenamente vigente. Este sería el supuesto típico de indemnización de daños y perjuicios o consecuencia de un incumplimiento contractual (interés de cumplimiento).

La propia Corte Suprema considera en este fallo "que el actuar de la institución bancaria, dado el tiempo transcurrido y el hecho de haber otorgado un préstamo complementario, el cual fue debidamente cursado, ha importado atentar contra la buena fe la cual se debe reparar en cuanto al daño sufrido por la actora, en la medida de los gastos contraidos por esta última durante la etapa preliminar de una negociación hecha en vista de la celebración del contrato, así como la pérdida de oportunidades similares causadas por las tratativas pendientes, que no hacen más que reafirmar la procedencia de la acción indemnizatoria"24.

Este punto merece un acercamiento hacia la buena fe alegada en juicio por el banco, nos parece que un profesional con conocimientos técnicos debe conducirse con un cuidado que razonablemente quepa esperar y, en particular, según las legítimas expectativas de los consumidores ${ }^{25}$.

Insistimos, este caso pudo haberse fallado de otra forma, pero no cabe duda que la Corte Suprema razona también en términos de la ley del consumidor vigente a la época en que los daños alegados en juicio se produjeron. De acuerdo al artículo 12 de la ley 19.496: "Todo proveedor de bienes o servicios estará obligado a respetar los términos, condiciones y modalidades conforme a las cuales se hubiere ofrecido o convenido con el consumidor la entrega del bien o la prestación del servicio". A este cliente se le quitó intempestivamente el financiamiento para la adquisición del inmueble y se le quitó sentido al crédito que ya había obtenido para repararla y modificarla a su gusto. Evidentemente el banco no ha respetado los términos en que se ha obligado, por lo que no es de extrañar que se haya obligado al pago del interés negativo ya que se acogió "la acción intentada, en la sección que pretende el pago de los gastos operacionales en que incurrió el actor, quedando su determinación para la etapa de cumplimiento

23 Morales Moreno (2010) p. 420. En el mismo sentido, Fenoy Picón (2010) pp. 116 a 130; también, García Rubio (2010) pp. 1640 a 1642. "Los PECL regulan, también, de modo especial, la incorporación al contrato de la información que ofrece un profesional, proveedor de bienes o servicios, sobre las cualidades de los mismos, a través de declaraciones públicas [art. 6:101 (2) PECL]. O la ofrecida por un sujeto distinto por cuya cuenta actúa el vendedor, o situado más arriba en la cadena de distribución [art. 6:102 (3) PECL]. Este régimen especial facilita la incorporación al contrato de la información suministrada. La vinculación no se funda en la confianza concreta de la otra parte contratante. Las afirmaciones vinculan por si mismas, salvo que la parte no profesional conozca su inexactitud (art. 6:101 (2) PECL). La ponderación de los intereses típicamente implicados en este supuesto justifica la regla, que refuerza la protección del consumidor, al limitar la discusión”. Morales Moreno (2012) p. 421.

24 "Urrea Fuentes, Cristian con Corpbanca" (2012) Considerando tercero de la sentencia de la Corte Suprema.

25 En el mismo sentido, artículo 2:102, "Expectativas legítimas”, establecidas en el Marco Común de Referencia (DFCR). 
del fallo"26. El resarcimiento alcanza al daño que la parte experimentó por haber confiado honestamente en la validez del futuro contrato. No alcanzaría, desde este punto de vista, al "interés contractual positivo" que comprendería todas las ventajas patrimoniales resultantes si el contrato se hubiere celebrado. Es por ello que como indemnización no se puede pedir una obligación de hacer, es decir, que el juez obligue a aquel que se apartó de la negociación a contratar con el que se siente defraudado en la etapa precontractual ${ }^{27}$.

Las partidas a indemnizar en estos casos pueden consistir en el daño emergente o lucro cesante provocados, como es el caso de esta sentencia. Desde el punto de vista del lucro cesante, hay que tener en cuenta que la formalización y posterior ejecución del contrato puede también haber impedido al comprador obtener una ganancia. La Corte Suprema cree que en este caso se pudieran haber rechazado otras ofertas de negocio ya que "se colige además de todo ello que el actuar de la institución bancaria, dado el tiempo transcurrido y el hecho de haber otorgado un préstamo complementario, debidamente cursado, implicó atentar contra la buena fe la cual se debe reparar en cuanto al daño sufrido por la actora, en la medida de los gastos contraidos por esta última durante las tratativa (sic) hechas en vista de la celebración del contrato, así como de la pérdida de oportunidades similares generadas por las tratativas pendientes, lo que no hace más que reafirmar la procedencia de la acción indemnizatoria impetrada"28.

La indemnización del "interés negativo", en un caso como este, tiene la misma finalidad que toda indemnización: devolver el patrimonio de la persona que ha sufrido el detrimento al mismo estado en que se hallaría si no se hubiera producido el daño patrimonial en primer lugar y extrapatrimonial, después ${ }^{29}$.

El "interés contractual negativo", es decir, aquel que se irroga a quien confía en la validez de un negocio jurídico que luego resulta defraudado por su no realización, presupone por hipótesis un contrato frustrado, una convención o vínculo jurídico que no produce y no llegará a producir sus efectos. Las causas de la indemnización por el "interés contractual negativo", por lo tanto, existen con anterioridad a la celebración del contrato si este llega a materializarse, resultando propio de la fase precontractual ${ }^{30}$.

No lo dice la Corte Suprema en su fallo, pues solo aporta "Que se acoge la acción intentada, en la sección que pretende el pago de los gastos operacionales en que incurrió el actor,

26 "Urrea Fuentes, Cristian con Corpbanca" (2012) Considerando quinto de la sentencia de la Corte Suprema.

27 La doctrina del "interés negativo", como indemnización posible por responsabilidad in contrahendo, fue acogida por algunos Códigos (artículo 198 del Código Civil griego; $\$ 45$ del Código Civil checoslovaco de 1950; 1338 y 1398 del Codice italiano vigente; $\$ \$ 122,307$ y 309 del B. G. B. (modificados en algunos pasajes en 2001); Código civil portugués de 1966, artículo 227. El art. 227 del Código Civil portugués dispone que "quien negocia con otro para la conclusión de un contrato debe, tanto en los tratos preliminares como en la formación del mismo, proceder según las reglas de la buena fe, bajo pena de responder por los daños que culposamente cause a la otra parte". Sobre estos códigos y sus regulaciones de las tratativas preliminares, De Los Mozos (2001) pp.177 y ss.

28 "Urrea Fuentes, Cristian con Corpbanca" (2012) Considerando decimotercero de la sentencia de la Corte Suprema.

29 En los "Principles of European Tort Law", a propósito del artículo 2:102. relativo a los "Intereses protegidos" en el número (4) se señala que "la protección de intereses puramente patrimoniales (...) puede tener un alcance más limitado. En tales casos debe tenerse en cuenta, de modo especial, la proximidad entre el agente y la persona protegida, o el hecho de que el agente es consciente de que causará un daño a la víctima a pesar de que sus intereses sean necesariamente objeto de una valoración inferior a los de esta".

30 Fischer (1928) pp. 97 y ss. 
quedando su determinación para la etapa de cumplimiento del fallo"31, pero el monto de los perjuicios que se discutirán debiera considerar los gastos que el comprador ha realizado como consecuencia de la futura conclusión o de la ejecución del contrato, tales como los gastos de movilización, notario, conservadores, peritajes de todo tipo, mejoras efectuadas y solicitadas por el futuro comprador a la cosa vendida, mejoras efectuadas y solicitadas por el futuro arrendatario a la cosa arrendada, si fueran del caso, los gastos hechos por los mandatarios para la ejecución del mandato, asesoramientos, pérdidas de oportunidades demostrables de otros negocios con terceros, entre otros. Lo que debiera indemnizarse son, en definitiva, los "daños de la confianza", por haber promovido en la otra parte genuinas perspectivas de que el contrato se ultimaría y de que las tratativas eran serias y conducentes a un vínculo jurídico definitivo entre las partes.

La Corte suprema confirma con este fallo la línea jurisprudencial de precedentes anteriores y delimita la protección de los dañados por culpa in contrahendo. Para ella, "establecida la naturaleza extracontractual de la responsabilidad precontractual, se debe dilucidar cuáles son los requisitos para que opere dicha responsabilidad, y por tanto, nazca la obligación de reparar los daños causados. Los elementos que deben estar presentes en este tipo de responsabilidad civil, de carácter extracontractual, son: a) La creación de una razonable confianza en la conclusión o perfeccionamiento del contrato proyectado; b) El carácter injustificado e intempestivo de la ruptura de los tratos preliminares; c) La producción de un daño en el patrimonio de una de las partes y d) La relación de causalidad entre el daño al patrimonio por un lado y la confianza que fue promovida y resultó defraudada por el otro negociante"32.

\section{IMPACTO DE LA LEY 20.555 EN LA LITIS TRABADA EN ESTE CASO}

¿Este caso tendría hoy el mismo tratamiento con la nueva ley 20.555 que modificó la 19.946? Creemos que no. Esta formación del consentimiento sobre el otorgamiento del crédito hipotecario, presenta algunas certezas mayores a día de hoy, gracias a la reforma.

Está definido en el reglamento sobre información al consumidor de créditos hipotecarios de la ley 19.496 qué es un crédito hipotecario, dificultad que el fallo que analizamos tuvo que despejar ${ }^{33}$. En efecto, crédito hipotecario es, de acuerdo al artículo tercero, núme-

31 "Urrea Fuentes, Cristian con Corpbanca" (2012) Considerando quinto de la sentencia de la Corte Suprema.

32 Por todos estos fallos, Jiménez con Armijo (2011) donde se resume la línea jurisprudencial actual y los elementos que han de tenerse en cuenta en un caso de responsabilidad precontractual en el voto de mayoría.

33 Una de las defensas del banco en este caso, recaía sobre el siguiente raciocinio: "el artículo 69 numeral $7^{\circ}$ de la Ley General de Bancos, puesto que resulta irrelevante que se trate de un crédito con garantía hipotecaria, toda vez que no es efectivo que la aprobación del mismo no se perfecciona sino hasta que se concluya el estudio de los títulos de la propiedad que se dará en garantía y se haga su tasación. Tal afirmación resulta errónea, porque se confunden dos contratos distintos: el de préstamo de dinero y el de hipoteca. Así, el artículo en cuestión señala que los bancos podrán otorgar créditos que se encuentren amparados por garantías hipotecarias. La norma no habla de créditos hipotecarios, puesto que ellos jurídicamente no existen. Si existen los contratos de mutuo de dinero que pueden caucionarse con garantías inmobiliarias, como la hipoteca. Por lo tanto, se infringe por errónea aplicación, la disposición citada, cuando se afirma por el fallo impugnado que el banco habia preaprobado el crédito, que no significa una aprobación definitiva, por cuanto debía esperar el estudio de títulos y la tasación del inmueble, ya que esto último es necesario para determinar si se otorga o no el contrato de hipoteca, pero no el contrato de mutuo, el que ya habia sido formalmente aprobado". "Urrea Fuentes, Cristian con Corpbanca" (2012) Considerando primero de la sentencia en comento. 
ro uno, del citado reglamento: "El producto financiero en virtud del cual una parte denominada proveedor, entrega o se obliga a entregar una cantidad cierta de dinero a otra parte denominada consumidor, que se obliga a pagarla en cuotas y en un plazo determinado, incluyendo la suma de dinero que resulte de la aplicación de una tasa de interés establecida al momento de su contratación, y a asegurar el pago constituyendo una hipoteca sobre el inmueble adquirido u otro que lo garantiza, y cuya finalidad es la adquisición, construcción, ampliación o reparación de inmuebles o la libre disposición del dinero entregado por el Proveedor.

También es crédito hipotecario el que tiene por objeto refinanciar créditos hipotecarios preexistentes y el que se otorga para los objetos señalados en este artículo mediante la emisión de letras de crédito, según lo dispuesto en el decreto con fuerza de ley $\mathrm{N}^{\circ} 3$ del Ministerio de $\mathrm{Ha}$ cienda, de 1997, que contiene el texto refundido, coordinado y sistematizado de la Ley General de Bancos, al cual le serán aplicables las disposiciones de este reglamento compatibles con la regulación contenida en leyes especiales y normas dictadas conforme a ellas".

Desde este 31 de julio de 2012, de acuerdo al artículo tercero, número veintiocho, del citado reglamento, una cotización es una propuesta dirigida nominativamente a un consumidor interesado en la contratación de un crédito hipotecario cuyo riesgo comercial ha sido previamente evaluado calificándosele como sujeto de crédito, en la que se debe indicar en forma clara, simple y transparente la información en las cotizaciones regulada en el artículo cuatro.

Si la propuesta se dirige al público o a un consumidor cuyo riesgo comercial no ha sido previamente evaluado, solo tendrá el carácter de simulación no vinculante o meramente referencial, hasta que se haya aprobado la evaluación de riesgo comercial, situación que deberá informarse en la misma simulación.

De acuerdo al artículo $8^{\circ}$ reglamento sobre información al consumidor de créditos hipotecarios de la ley 19.496, las cotizaciones no podrán tener una vigencia menor a siete días hábiles a contar de su comunicación al Consumidor interesado en la contratación de un crédito hipotecario cuyo riesgo comercial ha sido previamente evaluado calificándosele como sujeto de crédito. Sin perjuicio de lo anterior, las cotizaciones que se otorguen en virtud de una promoción u oferta se mantendrán vigentes por todo el periodo que estas últimas se extiendan, pero si el consumidor solicita una cotización en el marco de la promoción u oferta dentro de los siete días hábiles anteriores al vencimiento de la promoción u oferta, la vigencia de la cotización se reducirá al tiempo que reste para el término de la respectiva promoción u oferta.

En caso que se contrate el crédito hipotecario junto con otros productos o servicios simultáneamente, o que el crédito hipotecario conlleve la contratación de otros productos o servicios conexos, deberá suscribirse adicionalmente el respectivo contrato e insertarse un anexo en que se identifiquen cada uno de los productos o servicios contratados, estipulándose claramente cuáles son obligatorios por ley y cuáles voluntarios, debiendo ser aprobados expresa y separadamente cada uno de dichos productos y servicios conexos por el consumidor mediante su firma en el mismo.

Ahora bien, y para efectos de nuestro análisis de este caso, hoy es un deber expresar las razones del rechazo a la contratación del crédito hipotecario. El consumidor podrá requerir al proveedor un informe escrito en que consten las razones del rechazo a la contrata- 
ción del crédito hipotecario, las que deberán fundarse en condiciones objetivas, de acuerdo al artículo diecinueve del reglamento sobre información al consumidor de créditos hipotecarios de la ley 19.496, Título III, denominado "Razones de rechazo a la contratación de un crédito hipotecario". El consumidor podrá requerir el informe escrito, el que deberá entregársele hasta los diez días hábiles siguientes a la fecha en que se comunique por cualquier medio físico o tecnológico el rechazo de la contratación referida.

\section{CONCLUSIÓN}

1.- Consolida la Corte Suprema la línea de protección de intereses precontractuales que ha venido exhibiendo en varios fallos del último tiempo. La mala fe precontractual ya ha resultado delimitada y consiste, en el caso de la ruptura injustificada de la relación precontractual, en iniciar los tratos sin intención seria de contratar, o de prolongarlos sin querer concluir las negociaciones, o romper las negociaciones unilateralmente sin motivo justificado, tal y como ocurrió en este caso, según reza la propia sentencia del máximo tribunal.

2.- En la sentencia que hemos analizado, probablemente, con la actual legislación el banco fundaría el rechazo en la insuficiencia de garantías muebles o inmuebles, personales o reales, del cliente. Además, es de suponer, que el demandante en esta causa hubiera requerido informe escrito al banco sobre el crédito contratado y la respuesta definitiva del otorgamiento o no del mutuo hipotecario, sobre todo si pasaron casi diez meses sin respuesta alguna.

3.- El problema que plantean las modificaciones a la ley del consumidor es el mismo que ha aparecido en todas las legislaciones de consumo más avanzadas que la nuestra, ¿̇estarán dispuestos los consumidores a exigir sus derechos? Y, una vez que los ejerzan, ¿cuáles son las sanciones a quien no cumple? En la causa que motiva este comentario con la actual legislación, ¿qué pasa si el banco no contesta en los diez días por escrito del rechazo o la aprobación del crédito? El reglamento sobre información al consumidor de créditos hipotecarios de la ley 19.496 no lo aclara en su artículo 19. Sí se señala algo más en la propia ley, el artículo 17 letra $\mathrm{K}$, ya que expone que el incumplimiento de los reglamentos dictados para la ejecución de las nuevas normas, será sancionado con multa de hasta setecientas unidades tributarias mensuales.

4.- Finalmente, en un caso como este, y para conciliar con uno de los aspectos tratados en el comentario, a nuestro juicio debiéramos aplicar el artículo diecisiete letra L de la ley 19.496, ya que el banco entregó claramente información que indujo a error al consumidor, sin la cual no se hubiere contratado el servicio o producto. Esto está sancionado con multa prevista en el artículo 24 de la misma ley, que incluso da reglas para su valoración: cuantía de lo disputado, los parámetros objetivos que definan el deber de profesionalidad del proveedor, el grado de asimetría de información existente entre el infractor y la víctima, el beneficio obtenido con motivo de la infracción, la gravedad del daño causado, el riesgo a que quedó expuesta la víctima o la comunidad y la situación económica del infractor. Todo lo anterior, señala el citado artículo diecisiete letra L, sin perjuicio de las indemnizaciones que pueda determinar el juez competente de acuerdo a la ley del consumidor. ¿Cuáles? Nulidad parcial o total del acto, ¿perjuicios?, ¿patrimoniales o extrapatrimoniales?, ¿pérdidas 
de oportunidades? ¿Responsabilidad por Culpa in contrahendo? Ahondaremos en otro sitio sobre estas cosas, si Dios quiere, y a propósito de nuevas investigaciones en la materia.

\section{BIBLIOGRAFÍA CITADA}

Carrasco Perera, Á. (2010): Derecho de contratos (Thomson Reuters-Aranzadi) 1.319 pp. De la Maza Gazmuri, Iñigo (2010): "A propósito del artículo 1861 del Código Civil”, en Departamento de Derecho Privado de la Universidad de Concepción (coord.), Estudios de Derecho Civil V (Santiago, LegalPublishing) pp. 455-469.

De los Mozos, José Luis (2001): "Responsabilidad en los "tratos preparatorios" del contrato", en "Estudios de Responsabilidad Civil" en homenaje al profesor Roberto López Cabana (Ciudad Argentina y Dykinson editores, Madrid) pp.177 y ss.

Díez-Picazo, Roca Trías E. y Morales Moreno A. M. (2002): Los principios del Derecho europeo de contratos (Ed. Civitas, Madrid) 529 pp.

European Group on Tort Law (2005): "Principles of European Tort Law" (European Centre of Tort and Insurance Law, Springer Wien New York) 282 pp.

Fenoy Picón, Nieves (2010): "La modernización del régimen del incumplimiento del contrato: Propuesta de la Comisión General de Codificación. Parte primera: Aspectos generales. El incumplimiento", en $A D C$, pp. 116 a 130.

Ferrara, F. (1940): Teoria dei Contratti (Napoli) 418 pp.

Fischer, Hans A. (1928): "Los daños civiles y su reparación" (Traducción al español de Wenceslao Roces, Publicación Gráfica Universal, Madrid) 314 pp.

García Rubio, María Paz (2011): "La responsabilidad precontractual en la propuesta de modificación del derecho de obligaciones y contratos", http://www.mjusticia.gob.es/cs/Sa tellite/1292344316209?blobheader=application\%2Fpdfóblob. (fecha de consulta, 21 de septiembre de 2012)

Hoog, Martin (2011): Promises and contract law (Cambridge University Press) pp. 505.

Larrosa Amante, Miguel Ángel (2011): Derecho de consumo, Protección legal del consumidor (El Derecho, Madrid) 435 pp.

Manzanares Secades, A. (1985): "La responsabilidad precontractual en la hipótesis de ruptura injustificada de las negociaciones preliminares" en Anuario de Derecho Civil, Tomo XXXVII, fascículo III, julio-septiembre, 699 pp.

Medina Alcoz, María (2005) "La ruptura injustificada de los tratos preliminares: notas acerca de la naturaleza de la responsabilidad precontractual", en Revista de Derecho Privado, España, No 5-6/2005.

Morales Moreno, Antonio Manuel (2012): ¿Es posible construir un sistema precontractual de remedios? Reflexiones sobre la propuesta de modernización del derecho de obligaciones y contratos en el marco del derecho europeo" en "Derecho privado europeo y modernización del Derecho contractual en España". Klaus Jochen Albiez Dohrmann (coord.), María Luisa Palazón Garrido (coord.), María del Mar Méndez Serrano (coord.) (Atelier editores) $421 \mathrm{pp}$.

Morales Moreno, A. M.: (2010): "Incumplimiento del contrato y lucro cesante", Discurso leído el día 8 de febrero de 2010 en el acto de su recepción pública como Académico 
de Número por el Excmo. Sr. D. Antonio Manuel Morales Moreno y contestación del Excmo. Sr. D. Luis Díez-Picazo y Ponce de León, Madrid (2010). En iguales términos en "Incumplimiento del contrato y lucro cesante" (Editorial Aranzadi, S.A., Thomson/ Civitas, Navarra) pp. 400-422.

Ravazzoni, A. (1966): La formazione del contratto (Milano) Vol. I y II.

Rebollo Puig, Manuel, (2011): La defensa de los consumidores y usuarios (Iustel, Madrid) 2.088 pp.

Vidal Olivares, Álvaro (2011): "El incumplimiento y los remedios del acreedor en la propuesta de modernización del derecho de las obligaciones y contratos español". RChDP, Santiago, n. 16, jul. 2011. Disponible en <http://www.scielo.cl/scielo.php?script=sci_ arttext\&pid=S0718-80722011000100007\&lng=es\&nrm=iso >. (Fecha de consulta, 21 de septiembre de 2012).

Zimmermann, R., \& Whittaker, S. (2000): Good faith in European contract law: surveying the legal landscape. R. Zimmermann, \& S. Whittaker (Eds.), Good Faith in European Contract Law (Cambridge, Cambridge University Press) 723 pp.

\section{JURISPRUDENCIA CITADA}

Butler Machine Tool Co Ltd v. Ex-Cell-O Corporation (England) Ltd [1979] 1 WLR 401 (CA) 404 .

G. Percy Trentham Ltd v Archital Luxfer Lid [1993] 1 Lloyd's Rep 25 (CA) 27.

Jiménez con Armijo (2011): Corte Suprema, fallo de veintinueve de diciembre de dos mil once (acción por responsabilidad extracontractual), Disponible en http://www.poderjudicial.cl/modulos/TribunalesPais/TRI_esta402.php?rowdetalle=AAANoPAA1AAHV 96AAF \&consulta $=100 \&$ glosa $=\&$ causa $=1872 / 2010 \&$ numcua $=58029 \&$ secre $=$ UNICA (fecha de consulta: 21 de septiembre de 2012).

\section{NORMAS CITADAS}

Acuerdo $N^{\circ}$ 1495-03-090820 - Circular N³013-652 "A.- Financiamiento para la vivienda" y en el Capítulo II.A.1 "Normas sobre operaciones hipotecarias con letras de crédito". Banco Central de Chile.

\section{AGBGB}

BGB

Circular $N^{\circ} 3.427$ / 27.02.08 SBIF, disponible en http://www.sbif.cl/sbifweb3/internet/ archivos/norma_180_1.pdf (fecha de consulta 3 de septiembre de 2012).

Código Civil belga.

Código Civil checoslovaco.

Código Civil chileno.

Código Civil de la Federación Rusa.

Código Civil español.

Código Civil francés.

Código Civil griego. 
Código Civil italiano.

Código Civil luxemburgués.

Código Civil portugués.

Código de obligaciones suizo.

DCFR

Ley 19.496

Ley 20.555

Ley General de Bancos, cuyo texto fue fijado por el artículo único del decreto con fuerza de ley No 3, de 1997, del Ministerio de Hacienda. Modificada por la ley 20.448, artículo 9 número 2.

Principios Acquis

Principios Lando 